Surviving against the Odds

A John Hope Franklin Center Book 



\title{
Surviving
}

\section{against the Odds}

\author{
Village Industry in Indonesia
}

\author{
S. ANN DUNHAM
}

Edited and with a preface by

ALICE G. DEWEY and NANCY I. COOPER

With a foreword by Maya Soetoro-Ng

and an afterword by Robert W. Hefner

Duke University Press

Durham छ London

2009 
(C) 2009 Duke University Press

All rights reserved.

Printed in the United States of America

on acid-free paper $@$

Designed by C. H. Westmoreland

Typeset in Chaparral by Tseng Information Systems, Inc.

Maps drawn by Bill Nelson

Library of Congress Cataloging-in-Publication Data appear

on the last printed page of this book.

Unless otherwise specified, all photos are

provided by Bron Solyom.

We thank the University of Pennsylvania's Annenberg School

for Communication and John L. Jackson Jr., Ph.D., the Richard

Perry University Professor of Communication and Anthropology,

for their support. 


\section{(a)}

DEDICATED

TO MADELYN AND ALICE, who each gave me support in her own way,

TO BARACK AND MAYA, who seldom complained when their mother was in the field 
